\title{
Biochar persistence, priming and microbial responses to pyrolysis temperature series
}

\author{
Alice Budai $^{1,2}$ • Daniel P. Rasse ${ }^{1}$ - Alessandra Lagomarsino ${ }^{3}$ - Thomas Z. Lerch ${ }^{4}$. \\ Lisa Paruch ${ }^{1}$
}

Received: 12 December 2015 /Revised: 11 April 2016/Accepted: 17 April 2016 /Published online: 27 April 2016

(C) The Author(s) 2016. This article is published with open access at Springerlink.com

\begin{abstract}
Biochar and its properties can be significantly altered according to how it is produced, and this has ramifications towards how biochar behaves once added to soil. We produced biochars from corncob and miscanthus straw via different methods (slow pyrolysis, hydrothermal and flash carbonization) and temperatures to assess how carbon cycling and soil microbial communities were affected. Mineralization of biochar, its parent feedstock, and native soil organic matter were monitored using ${ }^{13} \mathrm{C}$ natural abundance during a 1-year lab incubation. Bacterial and fungal community compositions were studied using T-RFLP and ARISA, respectively. We found that persistent biochar-C with a half-life 60 times higher than the parent feedstock can be achieved at pyrolysis temperatures of as low as $370^{\circ} \mathrm{C}$, with no further gains to be made at higher temperatures. Biochar re-applied to soil previously incubated with our highest temperature biochar mineralized faster than when applied to unamended soil. Positive priming of native SOC was observed for all amendments but subsided by the end of the incubation. Fungal and bacterial community composition of the soil-biochar mixture changed increasingly with the application of biochars produced at higher
\end{abstract}

Alice Budai

alice.budai@nibio.no

1 Department of Soil Quality and Climate Change, Norwegian Institute of Bioeconomy Research, Høgskoleveien 7, 1430 Ås, Norway

2 Department of Environmental Sciences, Norwegian University of Life Sciences, box 5003, 1432 Ås, Norway

3 Consiglio per la ricerca in agricoltura e l'analisi dell'economia agraria, Agrobiology and Pedology Research Centre (CRA-ABP), Piazza M. d'Azeglio 30, 50121 Florence, Italy

4 Institute of Ecology and Environmental Sciences (IEES-Paris), Université Paris-Est Créteil (UPEC), 94010 Créteil, France temperatures as compared to unamended soil. Those changes were significantly $(P<0.005)$ related to biochar properties (mainly $\mathrm{pH}$ and $\mathrm{O} / \mathrm{C}$ ) and thus were correlated to pyrolysis temperature. In conclusion, our results suggest that biochar produced at temperatures as low as $370{ }^{\circ} \mathrm{C}$ can be utilized to sequester $\mathrm{C}$ in soil for more than 100 years while having less impact on soil microbial activities than high-temperature biochars.

Keywords Slow pyrolysis · Hydrothermal carbonization · Hydrochar · Flash carbonization · Microbial community composition
Abbreviations
CEC Cation exchange capacity
CC Corncob
$\delta^{13} \mathrm{C} \quad$ Stable carbon isotope composition
MS Miscanthus
RDA Partial redundancy analysis

\section{Introduction}

Biochar is composed of condensed poly-aromatic structures that are intrinsically resistant to microbial decomposition (Kuzyakov et al. 2014; Marschner et al. 2008), meaning biochar can potentially remain in soil for hundreds if not thousands of years (Preston and Schmidt 2006). Conversion of biomass into biochar and its addition to soil is a climate change solution which can sequester large amounts of biogenic $\mathrm{C}$, even in warm and moist climates where organic matter turnover rates are typically high (Cheng et al. 2008). The sustainable potential of biochar to mitigate climate change is estimated at $1.8 \mathrm{Pg} \mathrm{CO}_{2}-\mathrm{C}$ equivalents per year (Woolf et al. 
2010). Achievement of this potential will require a thorough understanding of the biochar production parameters that are optimal for producing high yields of stable biochar $\mathrm{C}$ at the lowest possible energy cost.

The resistance of biochar to microbial decomposition is dependent on its chemical composition resulting from the heat treatment, the highest treatment temperature reached during production (the carbonization temperature), and properties of the initial biomass (Conti et al. 2014; Enders et al. 2012). There is consensus that biochars produced at higher temperatures contain more aromatic structures, which confer intrinsic recalcitrance (Singh et al. 2012), but it is still not clear whether there is a temperature threshold at which relevant biomass transformations take place or whether there is a continuous response to production temperature (Wang et al. 2015). Chemical recalcitrance is only one aspect of $\mathrm{C}$ persistence in soil (Schmidt et al. 2011), and it is not clear which biochar properties might influence the persistence of biochar in soil through, e.g., physical and physicochemical protection mechanisms. Length of incubation has been shown to greatly influence the estimation of biochar mean residence time (Singh and Cowie 2014; Wang et al. 2015). This adds to the difficulty of comparing the persistence of materials from distinct incubation studies, and there is a need for incubation studies utilizing more than a few biochars produced along a temperature series.

Although abiotic processes are known to contribute to the degradation of biochar, soil microbes are the primary mediators of biochar decomposition (Wang et al. 2015). The composition and activity of microbial communities is influenced by changes in soil physical and chemical properties. Since biochar and hydrochar additions alter soil properties such as pH and moisture content and aeration (Gul et al. 2015), it is expected that the long-term persistence of biochars as well as that of native soil $\mathrm{C}$ is impacted by these amendments (Hernandez-Soriano et al. 2015). Charred plant residues contain compounds that are a food source to soil microbes (Farrell et al. 2013) or that act as signaling molecules that either stimulate or inhibit microbial activity and plant growth (Graber et al. 2010). For example, significant levels of organic compounds toxic to soil microbes have been identified in hydrochars (Becker et al. 2013), and this has contributed to doubts regarding the use of hydrochar for application to soil (Jandl et al. 2013). Reports in literature about the effect of biochar on soil microbial communities are contrasting: changes in soil physicochemical properties after biochar addition are suggested to be transient with no long-term effects on soil microbial communities (Quilliam et al. 2013) while significant effects have also been observed (Kolton et al. 2011). Adaptation of microbial communities in soils previously amended with biochar might also affect the decomposition of subsequent biochar additions to soil.

The present study aimed at testing four hypotheses: (1) the persistence in soil of biochars made from miscanthus and corncob feedstocks increases non-linearly with pyrolysis temperature, with little gain in stability expected beyond a given threshold; (2) biochar mineralization is not significantly increased in soils previously amended with biochars; (3) priming effect is induced by carbonization products and is affected by their production conditions; and (4) the soil microbial community composition is most affected by amendment with hydrochar and other low-temperature products while higher temperature biochars have a decreasing effect.

\section{Materials and methods}

\section{Soil and biochar materials}

The soil used for incubation was a sandy loam Inceptisol collected from an agricultural field in Rygge county, Norway $\left(59^{\circ} 23^{\prime} 15^{\prime \prime} \mathrm{N} ; 10^{\circ} 46^{\prime} 26^{\prime \prime}\right.$ E). Soil consisted of $83 \%$ sand, $11 \%$ silt, and $6 \%$ clay and had a TOC content of $12 \mathrm{~g} \mathrm{~kg}^{-1}$ (dw) and a $\mathrm{C} / \mathrm{N}$ ratio of 12 (Eurofins AS, Norway). The soil $\mathrm{pH}$ of 6.8 was determined in a 1:1 soil to water suspension. The air-dried soil was sieved $(<2 \mathrm{~mm})$ and moistened to $60 \%$ WHC prior to pre-incubation at $20^{\circ} \mathrm{C}$ for 14 days.

Two feedstocks were used to produce biochars and hydrochars: chaffed straw from Miscanthus giganteus and corncob from maize (Zea mays, ZP Maize Hybrid 505) grown in Serbia (Budai et al. 2014). In brief, corncob and miscanthus were exposed to slow pyrolysis at temperatures from 369 to $796{ }^{\circ} \mathrm{C}$, corncob alone was pyrolyzed at $235^{\circ} \mathrm{C}$ to produce a mild pyrolysis product, and both feedstocks were exposed to hydrothermal carbonization at $230{ }^{\circ} \mathrm{C}$ (Table 1). Additional corncob obtained from Waimanolo farm in Hawaii was exposed to flash carbonization. Detailed descriptions of the biochar production methods are reported by Budai et al. (2014). The resulting biochars and feedstocks were crushed through a 2-mm sieve with the exception of hydrochars which were ground using a mortar and pestle. Information about the yield, surface properties, and chemical composition of the products are already reported by Budai et al. (2014) and are summarized in Table 1. In addition, the yield of fixed $\mathrm{C}$ was calculated according to Eq. 1 where ash content of both the char and feedstock are corrected for:

Fixed C yield $(\%)=\left(\frac{100-\% V M-\% \mathrm{Ash}_{\text {char }}}{100-\% \mathrm{Ash}_{\text {feed }}}\right)$

\section{Incubation using the batch-flush headspace method}

\section{Long-term incubation}

Incubation of soil samples equivalent to $20 \mathrm{~g}$ on a dry weight basis was carried out at $20{ }^{\circ} \mathrm{C}$ in $120-\mathrm{mL}$ incubation vials 
Table 1 Chemical and physical properties of corncob (CC) and miscanthus (MS) exposed to hydrothermal carbonization (HTC), flash carbonization (Flash), and slow pyrolysis (Slow) (Budai et al. 2014)

\begin{tabular}{|c|c|c|c|c|c|c|c|c|c|c|c|c|}
\hline \multicolumn{2}{|c|}{ Feedstock/treatment } & \multirow[t]{2}{*}{$\begin{array}{l}\text { HTT } \\
\left({ }^{\circ} \mathrm{C}\right)\end{array}$} & \multirow{2}{*}{$\begin{array}{l}\begin{array}{l}\mathrm{pH}^{*} \\
\left(\text { in } \mathrm{H}_{2} \mathrm{O}\right)\end{array} \\
5.3\end{array}$} & \multirow{2}{*}{$\begin{array}{l}\mathrm{CEC}^{\#} \\
\left(\mathrm{cmol}_{\mathrm{c}} \mathrm{kg}^{-1}\right)\end{array}$} & \multirow{2}{*}{$\frac{\begin{array}{l}\mathrm{SA}^{* *} \\
\left(\mathrm{~m}^{2} \mathrm{~g}^{-1}\right)\end{array}}{2 \pm 0.1}$} & \multirow{2}{*}{$\begin{array}{l}\mathrm{VM}^{\#} \\
(\%)\end{array}$} & \multirow{2}{*}{$\begin{array}{l}\text { Fixed } C^{\alpha} \\
\text { yield }(\%) \\
17.7\end{array}$} & \multirow{2}{*}{$\begin{array}{l}C^{\# \#} \\
(\%) \\
48 \pm 0.7\end{array}$} & \multirow{2}{*}{$\frac{\begin{array}{l}\mathrm{H} / \mathrm{C} \\
\text { (ratio) }\end{array}}{1.6}$} & \multirow{2}{*}{$\frac{\begin{array}{l}\mathrm{O} / \mathrm{C} \\
\text { (ratio) }\end{array}}{0.89}$} & \multirow{2}{*}{$\begin{array}{l}\begin{array}{l}\mathrm{Mg} * \\
(\%)\end{array} \\
0.4\end{array}$} & \multirow{2}{*}{$\begin{array}{r}\begin{array}{l}\mathrm{K}^{*} \\
(\%)\end{array} \\
5.5\end{array}$} \\
\hline $\mathrm{CC}$ & Feedstock & & & & & & & & & & & \\
\hline & HTC & 230 & 4.1 & $30 \pm 0.5$ & $4 \pm 0.1$ & $67 \pm 0.1$ & & $60 \pm 0.8$ & 1.2 & 0.51 & 0.2 & 3.0 \\
\hline & Flash & 600 & 9.5 & $13 \pm 0.4$ & $39 \pm 2.9$ & $12 \pm 0.1$ & & $83 \pm 1.0$ & 0.3 & 0.08 & 1.8 & 20.4 \\
\hline & Slow & 369 & 9.2 & $21 \pm 0.2$ & $2 \pm 0.2$ & $35 \pm 1.0$ & 25.2 & $74 \pm 0.7$ & 0.7 & 0.24 & 0.8 & 14.0 \\
\hline & Slow & 416 & 10.1 & $16 \pm 0.5$ & $4 \pm 0.9$ & $26 \pm 0.2$ & 24.3 & $79 \pm 1.2$ & 0.6 & 0.17 & 0.8 & 13.3 \\
\hline & Slow & 562 & 9.4 & $13 \pm 1.3$ & $45 \pm 3.2$ & $13 \pm 0.1$ & 25.3 & $87 \pm 0.8$ & 0.4 & 0.08 & 1.1 & 16.9 \\
\hline & Slow & 796 & 9.4 & $5 \pm 0.0$ & $27 \pm 2.8$ & $7 \pm 0.1$ & 24.9 & $92 \pm 0.4$ & 0.1 & 0.04 & 1.2 & 18.6 \\
\hline \multirow[t]{9}{*}{ MS } & Feedstock & & 6.3 & $11 \pm 0.2$ & $2 \pm 0.4$ & $78 \pm 0.8$ & 13.7 & $48 \pm 0.9$ & 1.5 & 0.81 & 0.3 & 3.2 \\
\hline & HTC & 230 & 3.9 & $34 \pm 0.4$ & $6 \pm 0.1$ & $61 \pm 0.9$ & & $62 \pm 0.6$ & 1.1 & 0.43 & 0.2 & 1.1 \\
\hline & Slow & 235 & 7.2 & $11 \pm 0.7$ & $3 \pm 0.0$ & $72 \pm 1.9$ & 17.9 & $46 \pm 1.4$ & 1.4 & 0.65 & 0.5 & 3.9 \\
\hline & Slow & 369 & 8.3 & $20 \pm 0.4$ & $3 \pm 0.2$ & $40 \pm 0.3$ & 26.1 & $67 \pm 0.7$ & 0.8 & 0.25 & 0.9 & 7.6 \\
\hline & Slow & 385 & 8.7 & $21 \pm 0.5$ & $5 \pm 0.5$ & $31 \pm 0.7$ & 27.3 & $68 \pm 0.8$ & 0.7 & 0.22 & 1.1 & 8.1 \\
\hline & Slow & 416 & 10.2 & $21 \pm 0.5$ & $10 \pm 0.5$ & $20 \pm 0.4$ & 26.2 & $74 \pm 2.1$ & 0.5 & 0.13 & 1.2 & 10.0 \\
\hline & Slow & 503 & 10.3 & $18 \pm 0.5$ & $40 \pm 1.8$ & $16 \pm 0.6$ & 28.3 & $65 \pm 4.1$ & 0.4 & 0.11 & 1.4 & 8.5 \\
\hline & Slow & 600 & 10.0 & $14 \pm 0.1$ & $183 \pm 23.2$ & $10 \pm 1.3$ & 27.8 & $72 \pm 3.3$ & 0.3 & 0.06 & 1.4 & 9.6 \\
\hline & Slow & 682 & 10.3 & $16 \pm 0.3$ & $62 \pm 3.9$ & $6 \pm 0.4$ & 26.4 & $76 \pm 2.4$ & 0.2 & 0.05 & 1.3 & 10.8 \\
\hline
\end{tabular}

$C E C$ cation exchange capacity, $S A$ surface area, $V M$ volatile matter, $H T T$ highest treatment temperature

Set temperatures for hydrothermal carbonization, estimated values for flash carbonization (direct measurement was not possible), and directly measured for slow pyrolysis

${ }^{a}$ Calculated according to Eq. 1

$*_{n}=1$

$* *_{n}=2-8$

${ }^{\#} n=3$

\# $n=5$

equipped with butyl rubber septa. Biochar, hydrochar, and feedstock were added at rates of either 0.12 or $1.2 \%$ by dry weight, equivalent to 4 and $40 \mathrm{tha}^{-1}$, respectively, depending on the expected mineralization rate of the amendment (see Table 2 for biochar addition rates). These two different rates were used so that production rate of $\mathrm{CO}_{2}$ would be fairly similar among vials, so as to allow us to measure all samples at common dates. The rates themselves were determined based on our experience with soil incubation experiments (Moni et al. 2015). Gravimetric water content of the biocharsoil mixtures was $16.5 \%(\mathrm{~g} / \mathrm{g})$. This was maintained by injecting degasified water through the septa with a needle. Septa were punctured at irregular locations during sampling and replaced once to minimize gas diffusion through the septa. Vial headspace was initially flushed with $\mathrm{CO}_{2}$-free air to remove atmospheric $\mathrm{CO}_{2}$, which would otherwise interfere with partitioning the mineralized $\mathrm{C}$ to its source using two-pool calculations, as used in similar studies (Fontaine et al. 2004). At each measurement, the headspace was flushed with $\mathrm{CO}_{2}$ free air at $200 \mathrm{~mL} \mathrm{~min}^{-1}$ for $4 \mathrm{~min}$ and the displaced gasses collected in 1-L sampling gas bags. Both concentration and ${ }^{13} \mathrm{C}$ isotopic composition of $\mathrm{CO}_{2}$ in these samples were measured (see "Estimation of biochar mineralization"). Measurements with the simultaneous flushing and sampling, hereafter referred to as batch-flush headspace sampling, were performed every 6 to 16 days with higher frequency at the start of incubation. Frequent sampling ensured that headspace $\mathrm{CO}_{2}$ concentrations were not elevated to levels that would influence respiration rates. Biochar is a sorbent for $\mathrm{CO}_{2}$ (Creamer et al. 2014), and even short exposure to laboratory air has the potential to bias ${ }^{13} \mathrm{CO}_{2}$ measurements with atmospheric air. Because biochars produced at different temperatures have different $\mathrm{CO}_{2}$-sorption capacity (Creamer et al. 2014), it is important to reduce this artifact as much as possible in incubation studies looking at biochar series of production temperature. Our batch-flush headspace method was especially designed to allow for the collection and measurement of all $\mathrm{CO}_{2}$ produced by the biochar-soil mixtures while never exposing them to atmospheric air throughout the incubation period.

\section{Supportive incubation for previous biochar application}

A supportive incubation experiment was performed for 60 days using the batch-flush headspace method described 
Table 2 Modeled stability parameters of corncob (CC) and miscanthus (MS) exposed to hydrothermal carbonization (HTC), flash carbonization (Flash), and slow pyrolysis (Slow)

\begin{tabular}{|c|c|c|c|c|c|c|c|c|c|c|c|c|c|}
\hline \multicolumn{2}{|c|}{ Sample } & \multirow{2}{*}{$\begin{array}{l}\text { HTT } \\
\left({ }^{\circ} \mathrm{C}\right)\end{array}$} & \multirow{2}{*}{$\begin{array}{l}\delta^{13} \mathrm{C} \\
(\%)\end{array}$} & \multicolumn{2}{|c|}{$\begin{array}{l}\text { Application } \\
\text { rate }\end{array}$} & \multirow{2}{*}{$\begin{array}{l}\text { Mineralization } \\
\text { after } 364 \text { days } \\
\text { (\% of initial) }\end{array}$} & \multicolumn{4}{|c|}{ Two component exponential model ${ }^{\#}$} & \multirow[t]{2}{*}{$R^{2}$} & \multirow{2}{*}{$\begin{array}{l}\text { Estimated } \\
\text { half-life }^{* \alpha} \\
\text { (years) }\end{array}$} & \multirow{2}{*}{$\begin{array}{l}\text { Priming of SOC } \\
\text { after } 364 \text { days } \\
(\%)\end{array}$} \\
\hline & & & & $\begin{array}{l}(\% \\
d w)\end{array}$ & $\begin{array}{l}\text { (g C } \\
\mathrm{kg}^{-1} \\
\text { soil) }\end{array}$ & & $(\%)$ & (\%) & $\left(\%\right.$ year $\left.^{-1}\right)$ & $\left(\%\right.$ year $\left.^{-1}\right)$ & & & \\
\hline \multirow[t]{7}{*}{$\mathrm{CC}$} & Feedstock & 105 & -12.82 & 0.12 & 0.6 & $33.8^{\mathrm{a}}$ & 23.8 & 76.2 & 14.5 & 0.145 & 0.99 & $2.9^{\mathrm{a}}$ & $2^{\mathrm{a}}$ \\
\hline & HTC & 230 & -12.90 & 0.12 & 0.7 & $15.3^{\mathrm{b}}$ & 10.4 & 89.6 & 15.0 & 0.056 & 0.99 & $10.4^{\mathrm{b}}$ & $-1^{\mathrm{a}}$ \\
\hline & Flash & 580 & -12.97 & 1.2 & 9.8 & $0.6^{\mathrm{de}}$ & $<0.1$ & $>99.9$ & & 0.005 & 0.99 & $138^{\mathrm{de}}$ & $23^{\mathrm{a}}$ \\
\hline & Slow & 369 & -13.20 & 1.2 & 8.8 & $0.3^{\mathrm{f}}$ & $<0.1$ & $>99.9$ & & 0.003 & 0.99 & $252^{\mathrm{e}}$ & $7^{\mathrm{a}}$ \\
\hline & Slow & 416 & -13.37 & 1.2 & 9.3 & $0.5^{\mathrm{de}}$ & $<0.1$ & $>99.9$ & & 0.005 & 0.99 & $143^{\mathrm{de}}$ & $31^{\mathrm{a}}$ \\
\hline & Slow & 562 & -13.35 & 1.2 & 10.3 & $0.4^{\mathrm{ef}}$ & $<0.1$ & $>99.9$ & & 0.004 & 0.98 & $191^{\mathrm{de}}$ & $45^{\mathrm{a}}$ \\
\hline & Slow & 796 & -13.45 & 1.2 & 10.8 & $0.5^{\mathrm{de}}$ & $<0.1$ & $>99.9$ & & 0.005 & 0.98 & $149^{\mathrm{de}}$ & $58^{\mathrm{a}}$ \\
\hline \multirow[t]{10}{*}{ MS } & Feedstock & 105 & -12.38 & 0.12 & 0.6 & $38.7^{\mathrm{a}}$ & 30.1 & 69.9 & 8.4 & 0.129 & 0.99 & $2.6^{\mathrm{a}}$ & $16^{\mathrm{a}}$ \\
\hline & HTC & 230 & -12.62 & 0.12 & 0.8 & $10.1^{\mathrm{b}}$ & 6.1 & 93.9 & 14.2 & 0.044 & 1.00 & $14.2^{\mathrm{bc}}$ & $15^{\mathrm{a}}$ \\
\hline & Slow & 235 & -12.42 & 1.2 & 5.5 & $14.5^{\mathrm{b}}$ & $<0.1$ & $>99.9$ & & 0.165 & 1.00 & $4.2^{\mathrm{a}}$ & $47^{\mathrm{a}}$ \\
\hline & & & & 0.12 & 0.6 & $15.2^{\mathrm{b}}$ & $<0.1$ & $>99.9$ & & 0.170 & 1.00 & $4.1^{\mathrm{a}}$ & $24^{\mathrm{a}}$ \\
\hline & Slow & 369 & -12.70 & 1.2 & 7.9 & $0.5^{\mathrm{df}}$ & $<0.1$ & $>99.9$ & & 0.004 & 1.00 & $172^{\mathrm{de}}$ & $18^{\mathrm{a}}$ \\
\hline & Slow & 385 & -12.87 & 1.2 & 8 & $0.5^{\mathrm{df}}$ & $<0.1$ & $>99.9$ & & 0.004 & 1.00 & $165^{\mathrm{de}}$ & $33^{\mathrm{a}}$ \\
\hline & Slow & 416 & -13.15 & 1.2 & 8.7 & $0.6^{\mathrm{d}}$ & $<0.1$ & $>99.9$ & & 0.006 & 0.98 & $118^{\mathrm{d}}$ & $21^{\mathrm{a}}$ \\
\hline & Slow & 503 & -13.14 & 1.2 & 7.6 & $0.6^{\mathrm{de}}$ & $<0.1$ & $>99.9$ & & 0.006 & 1.00 & $125^{\mathrm{de}}$ & $2^{\mathrm{a}}$ \\
\hline & Slow & 600 & -13.19 & 1.2 & 8.5 & $0.3^{\mathrm{f}}$ & $<0.1$ & $>99.9$ & & 0.003 & 0.99 & $232^{\mathrm{e}}$ & $11^{\mathrm{a}}$ \\
\hline & Slow & 682 & -13.21 & 1.2 & 9 & $0.6^{\mathrm{de}}$ & $<0.1$ & $>99.9$ & & 0.006 & 0.99 & $123^{\mathrm{de}}$ & $51^{\mathrm{a}}$ \\
\hline \multicolumn{2}{|c|}{ Soil C } & & -27.28 & & 1.2 & $4.1^{\mathrm{c}}$ & 0.3 & 99.7 & 14.6 & 0.030 & 1.00 & $23.4^{\mathrm{c}}$ & \\
\hline
\end{tabular}

Different letters indicate significant differences $(P<0.05)$ according to one-way ANOVA Tukey test for three replicates

HTT highest treatment temperature

Original set temperatures for hydrothermal carbonization, estimated values for flash carbonization (direct measurement was not possible), and directly measured for slow pyrolysis (Budai et al. 2014)

\# Equation 3 was applied to cumulative data from the average of three replicates to obtain labile and recalcitrant carbon pool sizes and their mineralization rates

*Of the total C pool

Average of triplicates

above, to test for the effect of previous biochar application on the mineralization rate of newly added biochar. Miscanthus pyrolyzed at $416{ }^{\circ} \mathrm{C}$ (MS 416) was added to soils previously incubated for 344 days with and without amendment, and each soil was also incubated without the new biochar addition. Previous amendments consisted of miscanthus (MS) feedstock and MS hydrochar applied at a rate of $0.12 \%$, and MS 368 and MS 682 (slow pyrolysis biochars prepared at respective temperatures) applied at $1.2 \%$. New biochar was added at a rate of $2.3 \%$ by dry weight, corresponding to $78 \mathrm{t} \mathrm{ha}^{-1}$ field application rates, and moisture was maintained at $20 \%$ of the soil mixture. The percentage of $\mathrm{C}$ mineralized from amendment was calculated by the isotopic mixing model (Eq. 2) in all vials, and mineralization of the new biochar was taken as the difference between amendment mineralization in vials with and without new biochar amendment.

\section{Estimation of biochar mineralization}

The concentration and ${ }^{13} \mathrm{C}$ isotopic composition of headspace $\mathrm{CO}_{2}$ was measured using a cavity ring-down spectrometer (G1101-i, Picarro, INC., Sunnyvale, CA, USA) which had been factory upgraded to reduce transient concentration response, water vapor interference, and $\mathrm{CH}_{4}$ interference according to Moni and Rasse (2014). In addition, a Nafion filter with desiccator was installed on-line to further reduce possible interaction with water vapor.

The percentage of $\mathrm{CO}_{2}$ derived from corncob and miscanthus-derived residues ( $\% \mathrm{C} 4$ biomass) was calculated using the traditional mixing model of Balesdent and Mariotti (1996):

$\%$ C4 biomass $=100 \times \frac{\delta^{13} C_{\text {Meas }}-\delta^{13} C_{\mathrm{SOC}}}{\delta^{13} C_{C 4 \text { biomass }}-\delta^{13} C_{\mathrm{SOC}}}$ 
$\delta^{13} \mathrm{C}_{\text {Meas }}$ is the isotopic composition of the evolved $\mathrm{CO}_{2}$ during incubation and $\delta^{13} \mathrm{C}_{\mathrm{SOC}}$ and $\delta^{13} \mathrm{C}_{\mathrm{C} 4 \text { biomass }}$ are respective isotopic compositions of soil $\mathrm{C}$ and amendment. This equation assumes that there is no isotopic discrimination during the mineralization of feedstock, biochar, and SOC, i.e., that the $\delta^{13} \mathrm{C}$ of the emitted $\mathrm{CO}_{2}$ is equal to that of the corresponding substrate. If isotopic discrimination were to happen, it would mostly affect the early results of the incubation and would not change the relative responses among samples as long as this effect is consistent across biomass. The cumulative amount of $\mathrm{CO}_{2}$, in percent of initial, emitted over 364 days was calculated from individual headspace concentrations. The two-component exponential model

$C_{\text {total }}=C_{L} e^{\left(-k_{L} t\right)}+C_{R} e^{\left(-k_{R} t\right)}$

was used to partition $\mathrm{C}$ between relatively labile and more recalcitrant fractions of biochar (Nguyen et al. 2014; Singh et al. 2012). $C_{L}$ and $C_{R}$ are the respective labile and recalcitrant pool sizes, and $\mathrm{k}_{\mathrm{L}}$ and $\mathrm{k}_{\mathrm{R}}$ the respective decay constants for these pools. For the abovementioned reasons of possible early isotopic discrimination during decomposition, parameters of the first are more uncertain than those of the second and more meaningful recalcitrant pool. Half-life estimation of C4$\mathrm{C}$ was done using the parameters obtained from Eq. 4 and solving for $\mathrm{t}$, the half-life of the total $\mathrm{C}$ pool:

$50=C_{L}\left(1-e^{\left(-k_{L} t\right)}\right)+C_{R}\left(1-e^{\left(-k_{R} t\right)}\right)$

Priming of SOC was calculated from the mineralization rate of SOC in a sample amended with corncob or miscanthus residue ( Rate $_{\text {sample }}$ ) and the mineralization rate of SOC in a control sample containing only soil (Rate ${ }_{\mathrm{SOC}}$ ):

Priming $(\%)=\frac{\text { Rate }_{\text {Sample }}-\text { Rate }_{\text {SOC }}}{\text { Rate }_{\text {SOC }}} \times 100 \%$

\section{Microbial community fingerprinting}

Composition of bacterial and fungal communities was analyzed using terminal restriction fragment length polymorphism (T-RFLP) and automated ribosomal intergenic spacer analysis (ARISA), respectively. The DNA was first extracted from soil-biochar mixtures using a PowerSoil DNA Isolation kit (MOBIO Laboratories, Carlsbad, CA, USA) according to the manufacturer's instructions. Bacterial 16S rRNA genes were amplified using primers 63F (5'-CAGGCCTAACA CATGCAAGTC-3'), fluorescently labeled at the $5^{\prime}$ end with FAM dye, and 1389R (5'-ACGGGCGGTGTGTACAAG-3') (Marchesi et al. 1998). Fungal internal transcribed spacers (ITS) were amplified, using the primers ITS1F (5'-CTTGG TCATTTAGAGGAAGTAA-3') (Gardes and Bruns 1993) fluorescently labeled at the $5^{\prime}$ end with Yakima Yellow ${ }^{\circledR}$ dye and ITS4 (5'-TCCTCCGCTTATTGATATGC) (White et al. 1990). PCR were performed with $2 \mu \mathrm{L}$ of diluted DNA template $(0.5 \mathrm{ng} \mu \mathrm{L})$ in a total volume of $15 \mu \mathrm{L}$ (Master Mix Kit, Qiagen) and $0.05 \mathrm{mM}$ of each primer. Biorad T100 thermal cycler was used for the amplification with the following programs for T-RFLP: initial denaturation at $94{ }^{\circ} \mathrm{C}$ for $2 \mathrm{~min}$, followed by 30 cycles of $94{ }^{\circ} \mathrm{C}$ for $30 \mathrm{~s}, 57^{\circ} \mathrm{C}$ for $45 \mathrm{~s}$, and $72{ }^{\circ} \mathrm{C}$ for $90 \mathrm{~s}$, followed by a final extension time at $72{ }^{\circ} \mathrm{C}$ for 10 min. For ARISA, PCR conditions consisted of an initial denaturation at $95{ }^{\circ} \mathrm{C}$ for $5 \mathrm{~min}$, followed by 35 cycles of $95{ }^{\circ} \mathrm{C}$ for $30 \mathrm{~s}, 55^{\circ} \mathrm{C}$ for $30 \mathrm{~s}$, and $72{ }^{\circ} \mathrm{C}$ for $60 \mathrm{~s}$, followed by a final extension time at $72{ }^{\circ} \mathrm{C}$ for $10 \mathrm{~min}$. Bacterial PCR products $(10 \mu \mathrm{l})$ were digested with $10 \mathrm{U}$ of the restriction enzyme AluI and $1 \times$ restriction enzyme buffer (Thermo Fisher) in a total volume of $15 \mu \mathrm{l}$ at $37{ }^{\circ} \mathrm{C}$ for $3 \mathrm{~h}$. After a desalting step, $2 \mu \mathrm{l}$ of PCR products were mixed with formamide containing $0.5 \%$ of ROX-labeled GS500 (T-RFLP) or GS2500 (ARISA) internal size standard (Applied Biosystems) in a total volume of $12 \mu \mathrm{l}$ and denatured at $94{ }^{\circ} \mathrm{C}$ for $3 \mathrm{~min}$. Samples were electrophoresed on an ABI 3730 PRISM $^{\circledR}$ capillary DNA sequencer (Applied Biosystems). The T-RFLP and ARISA profiles obtained with the sequencer were analyzed using GeneMapper ${ }^{\circledR}$ v3.7 software (Applied Biosystems). The fragments between 50 and $500 \mathrm{bp}$ and peak heights $\geq 50$ fluorescence units were included in T-RFLP analysis and Amplicons between 200 and 1500 bp and peak heights $\geq 100$ fluorescence units were included for ARISA analysis. Fragments having a relative abundance of $<0.5 \%$ (peak area threshold) were removed from the matrices (Blaud et al. 2015).

\section{Statistical analysis}

Statistical differences induced by individual treatments were obtained from one-way ANOVA and the Tukey test (Sigmaplot 11.0). Cumulative C4 amendment mineralized after 364 days and the estimated half-life were log-transformed so that normal distribution and equal variance requirements were met before application of the one-way ANOVA Tukey test. Curvilinear fitting of the two-pool model was conducted with Sigma Plot 11.0.

For TRFLP and ARISA analysis, the total peak area for each profile was normalized across peaks (i.e., the area under each peak was divided by the total peak area of each sample) to account for run-to-run variations (Blaud et al. 2015). The similarity of Euclidean distances matrices obtained from each profile was determined using a Mantel test performed on $10^{5}$ permutations (Legendre and Fortin 1989). Partial redundancy analyses (RDA) were performed to explore the relationships between microbial community composition using either the TRFLP or ARISA dataset and biochar chemical properties. A forward selection allowed to find the most significant 
$(P<0.005)$ variables. All multivariate analyses were performed using the "ade4TkGUI" package in R.

\section{Results}

\section{Persistence of biochar series in soil}

Cumulative organic $\mathrm{C}$ mineralized after 364 days revealed three persistence ranges of materials, namely (1) noncarbonized feedstocks (MS and CC) with low persistence, (2) low-temperature materials prepared at $\leq 235^{\circ} \mathrm{C}$ consisting of hydrochars and a mild pyrolysis product (CC hydrochar, MS hydrochar, and MS $235^{\circ} \mathrm{C}$ ) with intermediate persistence, and (3) high-temperature biochars including slow pyrolysis biochars produced at $\geq 369{ }^{\circ} \mathrm{C}$ and flash carbonization char having high persistence (Fig. 1). A substantial fraction of the non-carbonized feedstocks were mineralized in 1 year (34 and $39 \%$ for CC and MS, respectively), while on average, only $0.5 \%$ of high-temperature biochars were converted to $\mathrm{CO}_{2}$ (Fig. 1 and Table 2). In comparison, between 10 and $15 \%$ of hydrochar and mild pyrolysis products were mineralized, which is about three times the proportion of SOM mineralized (4\%) during the same incubation.
Carbon mineralization kinetics was used to further differentiate the persistence of materials by fitting two-pool models to the cumulative mineralization curves. The models were able to describe the data well with $r^{2}$ values $\geq 0.98$ (Table 2). For flash carbonization and all slow pyrolysis biochar treatments, the labile pool was smaller than $0.1 \%$, indicating that the labile $\mathrm{C}$ component of these chars is negligible. Interestingly, the mild pyrolysis product did not have a significant labile pool. In contrast, non-carbonized feedstocks and hydrochars consisted of two pools, namely a labile and recalcitrant $\mathrm{C}$ pool (Table 2). SOM contained a small labile $\mathrm{C}$ pool. The recalcitrant pools of hydrochars, which determine the long-term residence time of the material, mineralized at rates closest to that of soil $\mathrm{C}$ (Table 2). The mineralization rates of high-temperature biochars were an order of magnitude lower than this (Table 2).

Estimated half-life of the sum of labile and recalcitrant $\mathrm{C}$ pools, obtained from the fitted models, provides a reliable estimate of the long-term persistence of the materials. Unlike the amount of cumulative $\mathrm{C}$ mineralized after 364 days, estimated half-life of the total $\mathrm{C}$ pool also takes into consideration the size of the more labile pool that controls the initial $\mathrm{C}$ mineralization rate. The estimated half-lives reveal that flash carbonization and slow pyrolysis at high temperatures produced materials that were on average 60 times

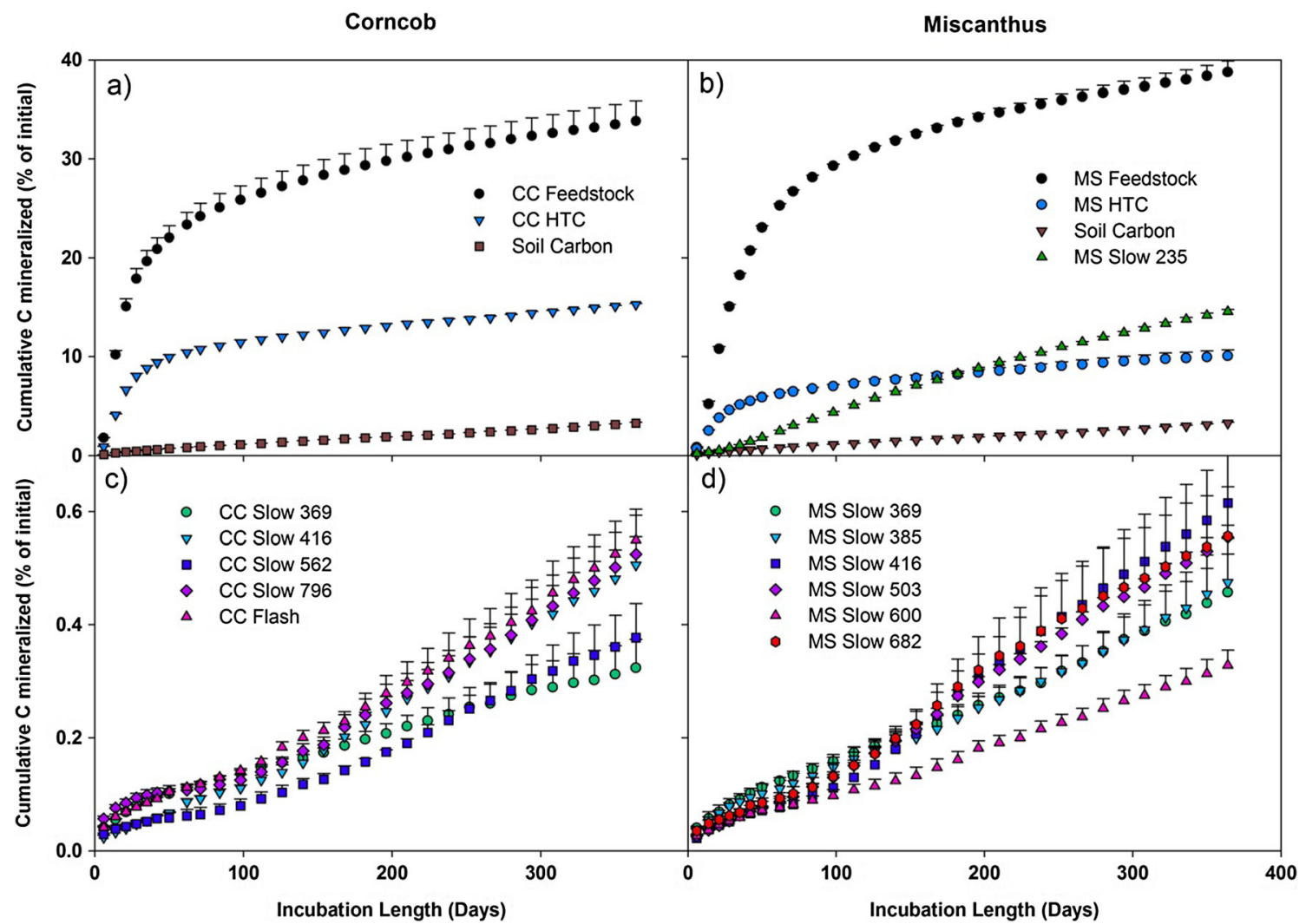

Fig. 1 Cumulative mineralization of corncob $(C C)$ and miscanthus $(M S)$ feedstocks, hydrochars (HTC), slow pyrolysis (Slow) chars, flash carbonization (Flash) chars, and soil $C$. Mean values and positive standard deviation error bars for three replicates are presented according to $\mathbf{a}, \mathbf{b}$ faster and $\mathbf{c}, \mathbf{d}$ slower mineralizing residues 
more recalcitrant than non-carbonized feedstocks and on average 7 times more recalcitrant than soil C. In comparison, mild pyrolysis at low temperatures produced a material with a half-life that is comparable to that of feedstocks, independent of the application rate. Hydrothermal carbonization on the other hand produced materials that were more recalcitrant than non-carbonized feedstocks in the long-term (3.6 and 5.5 times for CC and MS), and the half-lives of their total $\mathrm{C}$ were only slightly shorter or comparable to that of soil $\mathrm{C}$.

Highest treatment temperatures at or above $369^{\circ} \mathrm{C}$ did not have a substantial effect on biochar persistence with all estimated half-lives of biochar total $\mathrm{C}$ pools comprised between 118 and 252 years. The statistical differences observed between the relatively more recalcitrant CC 369 and MS 600 and the relatively more labile MS 416 do not reveal a consistent response to production temperature (Table 2). Pyrolysis at $235{ }^{\circ} \mathrm{C}$ generated a material with a half-life $<5$ years, which was much shorter than that of any other slow pyrolysis biochar. The fixed $\mathrm{C}$ yields from proximate analysis were low for both feedstocks and the mild pyrolysis product as compared to biochars (Table 1). Increase in pyrolysis temperature did not affect the fixed $\mathrm{C}$ yield of biochars.

On the basis of estimated half-lives of total $\mathrm{C}$ pools and mineralization kinetics, we identified a total of four groups of materials. First, non-carbonized feedstock, characterized by a large labile $\mathrm{C}$ pool and the shortest estimated half-life of its total C pools. Second, mild pyrolysis product produced at low temperature $\left(235^{\circ} \mathrm{C}\right)$, which did not contain a labile $\mathrm{C}$ pool but also displayed short estimated half-life of its total $\mathrm{C}$ pools. Third, hydrochar, which had a sizable labile $\mathrm{C}$ pool but displayed significantly longer half-life of its total $\mathrm{C}$ pools than non-carbonized feedstock. Finally, slow pyrolysis and flash carbonization biochar produced at temperatures $>370{ }^{\circ} \mathrm{C}$, which was significantly more recalcitrant than SOC.

\section{Persistence in previously biochar-amended soils}

The mineralization of MS 416 was significantly influenced by the previous biochar amendment. When MS 416 was added to soil previously exposed to MS 682 for 344 days, during the following 60 days of incubation, it decomposed on average twice than when it was incubated in soil previously exposed to other treatments such as those with MS 369, hydrochar, and non-carbonized feedstock or in the unamended soil (Fig. 2). Feedstock-treated soil led to faster mineralization of newly added biochar than soil treated with hydrochar or not treated with biochar. MS 416 mineralized at the same rate when added to soil previously exposed to MS 369 or hydrochar, as when added to the biochar-free control soil (Fig. 2).

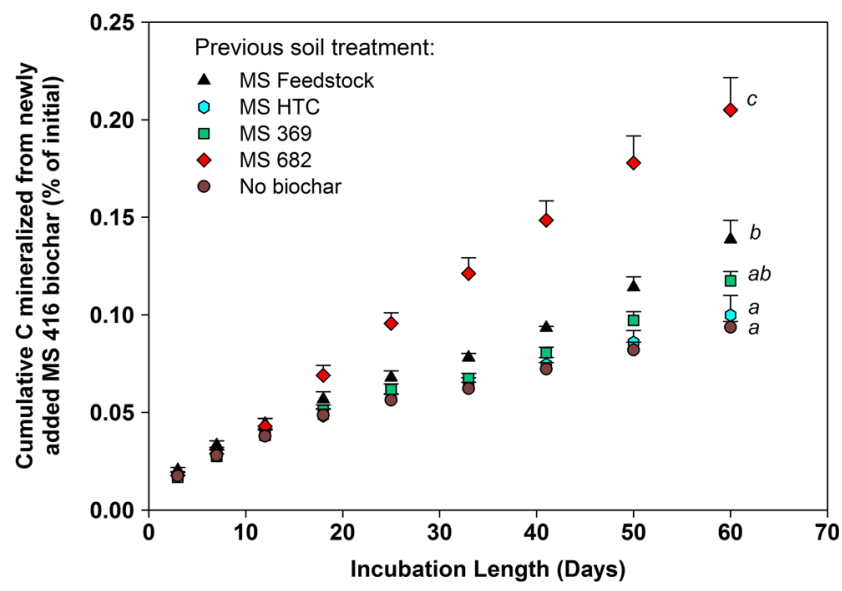

Fig. 2 Cumulative $\mathrm{C}$ mineralized from newly added biochar (MS 416) to soils previously amended with miscanthus $(M S)$ feedstock, hydrochar (HTC), or slow pyrolysis biochars prepared at 369 and $682{ }^{\circ} \mathrm{C}$. Positive error bars are shown for averages of three replicates and statistical differences are indicated using letters $(P<0.05$, one-way ANOVA Tukey test for three replicates)

\section{Priming of soil C}

Cumulated priming of native SOC after 364 days of incubation varied between -1 and $58 \%$ across all treatments (Table 2). Although this is a wide range, no statistical differences could be detected among individual treatments. Given the absence of significant differences among individual treatments, we explored group responses to see if general trends would emerge. First, all priming responses were grouped by feedstock of origin (Fig. 3a). The results from this analysis suggest that feedstock has no influence on priming, as the two responses were similar. Second, we grouped priming responses according to the four groups that we identified earlier: (1) non-carbonized feedstocks, (2) hydrochars, (3) mild pyrolysis product, and (4) biochars. The non-carbonized feedstocks and hydrochars had similar priming responses, which were lower than that of slow pyrolysis products (Fig. 3b). No difference in priming response occurred between the mild pyrolysis products and high-temperature biochars. For these latter products, the priming response ceased after 1 year of incubation when less than $5 \%$ of the original SOC had mineralized.

Priming was also evaluated in a 60-day re-incubation experiment conducted on samples previously incubated for 344 days. When samples were re-incubated without addition of new biochar amendment, the priming response agreed with those observed towards the end of the long-term experiment. A slightly negative priming effect was observed for the MS feedstock $(-8 \%)$ and hydrochar $(-18 \%)$ while positive priming responses were observed for slow pyrolysis biochars (MS 369 at $3 \%$ and MS 682 at $12 \%$ ) (Fig. 4). New addition of a high-temperature biochar, MS 416, did not modify these priming responses within 60 days: mineralization of soil $\mathrm{C}$ in MSand hydrochar-amended soils remained lower as compared to 


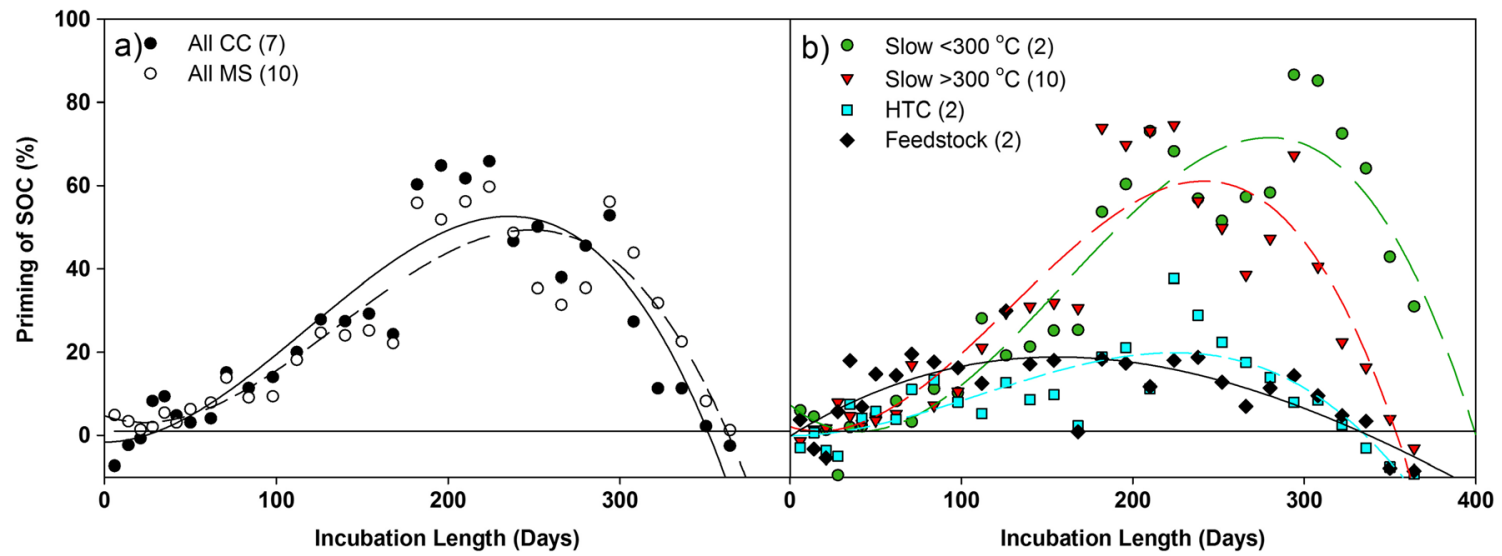

Fig. 3 Priming of SOC mineralization by feedstock and biochar products, grouped either by a feedstock of origin (corncob $(C C)$ and miscanthus $(M S)$ ), or $\mathbf{b}$ by product production method (slow pyrolysis (Slow), hydrothermal carbonization (HTC), and no treatment (Feedstock)). Treatments consist of triplicate samples, and the number

that of the soil control while the opposite was observed for soils amended with slow pyrolysis biochars (Fig. 4).

\section{Microbial community composition}

The difference in microbial community composition between control and amended soils increased with carbonization intensity of the amendment (Fig. 5). The response of bacterial and fungal communities was very similar, as suggested by the Mantel test performed on T-RFLP and ARISA matrices $\left(r^{2}=0.32 ; P<0.005\right)$. Flash carbonization char caused the greatest change in microbial community composition of the amended soil compared to control soil. For both bacterial and fungal communities, the mineralization rate of the amendment showed a significant $(P<0.05)$ spearman correlation with the

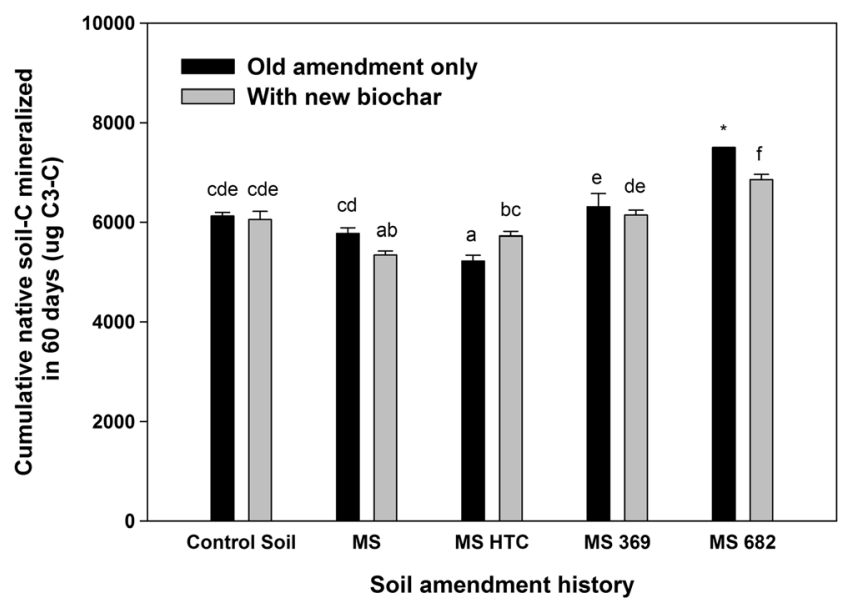

Fig. 4 Cumulative soil $\mathrm{C}$ mineralized with and without new biochar (MS 416) addition to soil previously exposed to feedstock (MS), hydrochar (HTC), or biochar (MS 369 and MS 682). Standard deviation for triplicates are shown except where marked (an asterisk symbol indicates that only two replicates were used). Significant differences between treatments are indicated using letters $(P \leq 0.001$, ANOVA Tukey test) of treatments within each group is shown in parentheses. Curves are third-order polynomial fits for the group averages. No statistical differences in cumulative priming were detected between groups using the Kruskal-Wallis one-way ANOVA on ranks

first axis of the RDA that explained most of the variability among treatments.

The RDA performed on T-RFLP and ARISA data showed that the main parameters that significantly $(P<0.005)$ shape bacterial and fungal communities were the $\mathrm{O} / \mathrm{C}$ ratio and $\mathrm{pH}$ and, to a lesser extent, $\mathrm{fC} / \mathrm{VM}$ ratio, and $\mathrm{Mg}$ and $\mathrm{K}$ concentrations.

\section{Discussion}

\section{Influence of pyrolysis temperature on biochar mineralization rate}

After 1 year of incubation, on average $0.5 \%$ of our hightemperature biochars were mineralized. This is less than or comparable to mineralization of miscanthus biochar reported elsewhere. After 87 days of incubation, Luo et al. (2011) observed 0.73 and $0.16 \%$ mineralization of miscanthus biochars produced at 350 and $700{ }^{\circ} \mathrm{C}$, respectively, while Bai et al. (2013) observed $1.1 \%$ mineralization of $575{ }^{\circ} \mathrm{C}$ miscanthus biochar after 200 days of incubation. Mineralization rates of corncob biochars have been little studied. There are a number of potential explanations for the observed difference in mineralization rates, including soil type and length of incubation (Wang et al. 2015). Similar to our findings, ryegrass biochar produced at $400{ }^{\circ} \mathrm{C}$ has an annual decomposition rate of $0.5 \%$ over a 3.5-year period (Kuzyakov et al. 2009). With longer incubation time of 8.5 years, decomposition of this char stabilized at a much lower rate of $<0.3 \%$, with a biochar half-life of 278 years (Kuzyakov et al. 2014). Longer mean residence time has also been reported after extending the 1-year incubation period to 2 years at room temperature (Fang et al. 2015). This suggests that the half-life of biochar in short-term studies is potentially underestimated. Results from the present 1-year 
a)

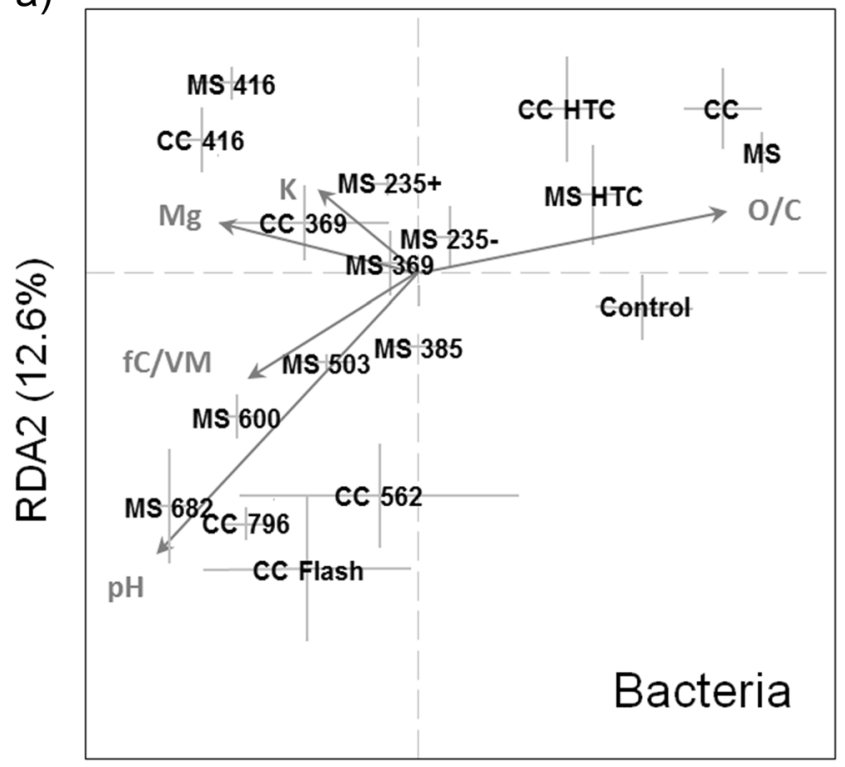

RDA1 (41.1\%)

b)

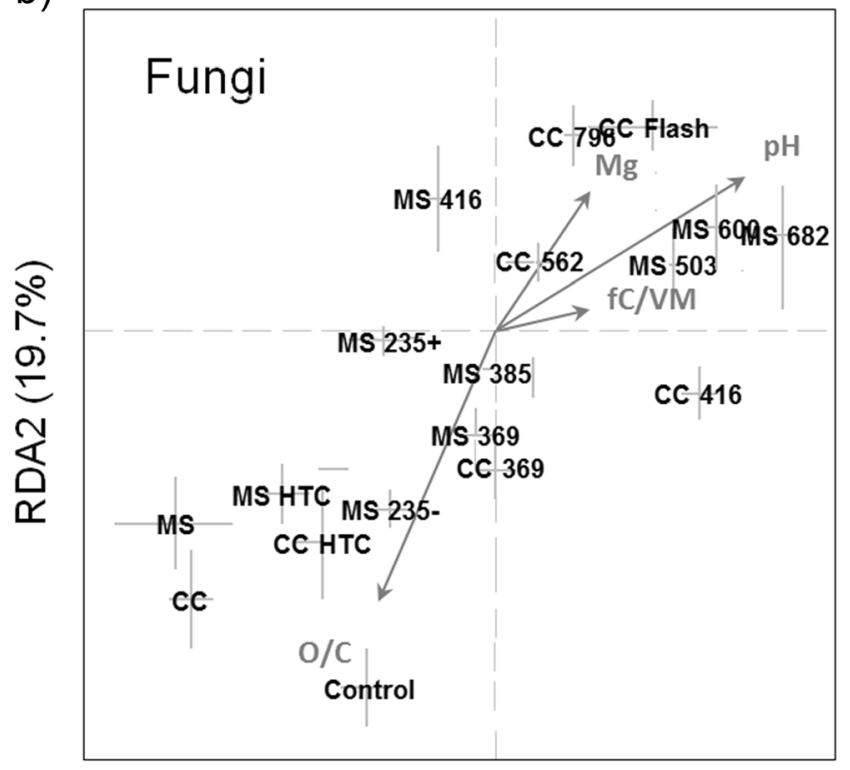

RDA1 (31.9\%)

Fig. 5 Community composition of $\mathbf{a}$ bacteria from TRFLP and $\mathbf{b}$ fungi from ARISA

incubation give an estimated half-life of 164 years for hightemperature biochars produced by both slow pyrolysis and flash carbonization. By contrast, our hydrochars of corncob and miscanthus displayed half-lives of 10.4 and 14.2 years, respectively, confirming that hydrochars are less resistant to decomposition than biochars (Kammann et al. 2012).

Our mild pyrolysis product had a shorter half-life than the hydrochars despite similar proportions of the initial added products were mineralized after 1 year of incubation. Initially, the hydrochars decomposed faster, clearly displaying the presence of a labile pool. However, once this labile pool was exhausted, hydrochars decomposed at a slower rate than mild pyrolysis products. Schulze et al. (2016) also found hydrochars to have both a readily available $\mathrm{C}$ pool and a slower mineralizable pool. While hydrothermal carbonization of our feedstocks was found to transform hemicellulose completely and cellulose partially (Calucci et al. 2013), cellulose is not affected at temperatures of $200-230{ }^{\circ} \mathrm{C}$ during mild pyrolysis treatment (Singh et al. 2013). The different transformations of cellulose between hydrothermal and mild pyrolysis treatments may explain the slower decomposition rate of hydrochars in the long than short run.

Because absolute mineralization rates obtained under laboratory incubations are not necessarily representative of field conditions (Ventura et al. 2014), we also used the comparative mineralization response of biochar vs. native SOM as an indicator of potential mineralization rates in the field. We found that high-temperature biochars from both slow pyrolysis and flash carbonization methods are 7 times more resistant to decomposition than SOM while our hydrochars of corncob and miscanthus displayed half-lives most similar to that of SOM. Considering that the overall average mean residence time of SOM in the field is estimated at 50 years (Schmidt et al. 2011) with a half-life of about 35 years, high-temperature biochars were 7 times more recalcitrant than SOM exceeding the 100year definition of permanent storage as given by Noble et al. (2000).

Persistence in soil incubations increased dramatically for our biochars prepared above temperatures of $235^{\circ} \mathrm{C}$ and reached a plateau for biochars prepared at $370{ }^{\circ} \mathrm{C}$. This is consistent with findings that the greatest change in biochar properties occurs between 200 and $400{ }^{\circ} \mathrm{C}$ (Al-Wabel et al. 2013; Zhang et al. 2015). In addition, we show that there was little gain if any in fixed $\mathrm{C}$ yield from proximate analysis beyond the temperature threshold. A lack of increase in stable $\mathrm{C}$ yield with increased production temperature indicates no gain in $\mathrm{C}$ sequestration potential with increased carbonization intensity (Masek et al. 2013). Braadbaart et al. (2004) identified a production temperature threshold of $310{ }^{\circ} \mathrm{C}$ for pea biomass. By contrast, other studies have reported that production temperatures above these values lead to increased recalcitrance. For example, Fang et al. (2015) showed that biochar produced at $550{ }^{\circ} \mathrm{C}$ has a mean residence time significantly longer than that of biochar produced at $450^{\circ} \mathrm{C}$. Similar to our results, Whitman et al. (2013) observed that production temperature above or equal to $350{ }^{\circ} \mathrm{C}$ does not increase the persistence of slow pyrolysis biochars in soil. The recent metaanalysis by Wang et al. (2015) also points towards the existence of a threshold for recalcitrance based on pyrolysis temperature. Our results strongly suggest that with no increase in recalcitrance above a fairly low temperature threshold, maize and miscanthus biochars can be tailored for their agronomic potential without compromising biochar recalcitrance. 


\section{Biochar induced transient priming effect of soil C}

Positive priming was observed within the 1-year period for all amendments but subsided by the end of the incubation. Both positive (Luo et al. 2011) and negative priming (Bamminger et al. 2014a), as well as no priming (Nguyen et al. 2014) of SOC by biochar addition has been reported in literature. Some studies report that priming decreases or becomes negative for higher temperature biochars and attribute this effect to reduced volatile and labile matter in the higher temperature biochars; contents of both residual pools was not sufficient to induce cometabolism of SOC (Luo et al. 2011; Zimmerman et al. 2011). However, a meta-analysis by Wang et al. (2015) reveals that slow pyrolysis products prepared below $374{ }^{\circ} \mathrm{C}$ led to on average more negative priming of SOC than hightemperature biochars. This indicates that several processes contribute to biochar effects on SOC decomposition. Our results are in line with those of Wang et al. (2015) as we showed that both feedstocks and hydrochars caused little positive priming compared to those of slow pyrolysis products, independent of production temperature. Therefore, co-metabolism does not appear to be the main driving mechanism for priming of SOM mineralization by our biochar series.

The largest priming effect we observed at any point in time approached $90 \%$ additional mineralization of SOC (Fig. 3), and the largest overall priming effect in the first year was $58 \%$ (Table 2). After one year, the priming effect diminished to zero for all amended soils, indicating that long-term priming effects are not likely to be substantial. Re-application of biochar in the second experiment also did not change the trends observed at the end of the long-term incubation. The transient nature of the positive priming we observed was also seen by Luo et al. (2011) using miscanthus biochar. Several studies have observed first positive and then negative priming effects of biochar on SOC during their incubation (Maestrini et al. 2014; Zimmerman et al. 2011). By contrast, studies have also observed the opposite with first negative and then positive priming effects of hydrochar (Malghani et al. 2013). Apparent positive priming (Blagodatskaya and Kuzyakov 2008) and the absence of roots, which otherwise have a direct effect on C turnover rates (Ventura et al. 2014), lead to the likely overestimation of priming of SOC measured in incubation studies (Qiao et al. 2014). The transient nature of the response we observed suggests that priming will have only minimal impact on the $\mathrm{C}$-sequestration gains obtained when incorporating biochar in agricultural fields.

\section{Change in microbial community composition with pyrolysis temperature}

In our experiments, soil microbial community composition was strongly affected by the degree of carbonization across our biochar series produced at different temperatures. The main properties affecting soil microbial composition were $\mathrm{pH}$ and $\mathrm{O} / \mathrm{C}$ ratio. The $\mathrm{pH}$ values of our biochars progressively increased with production temperature up to a plateau of 10 (Budai et al. 2014). Other studies have reported that the presence of basic sites on biochar structures increases with production temperature ( $\mathrm{Li}$ et al. 2014) and that the $\mathrm{pH}-10$ plateau corresponds to carbonate formation in biochars (Yuan et al. 2011). Soil $\mathrm{pH}$ is a major driver of microbial community composition (Fierer and Jackson 2006; Rousk et al. 2010; Watzinger et al. 2014). Prayogo et al. (2014) found that biochar application rate of $2 \%$ was able to change soil $\mathrm{pH}$ but not $0.5 \%$ rate while both application rates influenced microbial community composition analyzed by phospholipid fatty acid analysis. Our $1 \%$ biochar application rate had no significant effect on soil $\mathrm{pH}$ implying that the effect on microbial community composition was linked to $\mathrm{pH}$ of the biochar itself and not average $\mathrm{pH}$ of the soil. This suggests that the effect of biochar $\mathrm{pH}$ on microbial community composition in soil was localized on the biochar particles themselves or in their immediate vicinity.

It has been suggested that biochar might affect the microbial genome extraction efficiency (Lehmann et al. 2011), potentially due to a binding effect similar to that reported for $\mathrm{CO}_{2}$ (Creamer et al. 2014) and herbicides (Graber et al. 2012). Although it is impossible to ascertain that such an effect was not present in our study, we think that it is unlikely to bias our results. First, it is not clear why this effect would translate into gene-specific responses. Second, in a preanalysis of our results (data not shown), we found no effect of high-surface area as measured by $\mathrm{BET}_{\mathrm{N} 2}$, a good proxy for sorption, on the microbial community composition of the soilbiochar mixtures. However, it should be mentioned that the taxonomic resolution of molecular fingerprints used here (TRFLP and ARISA) only give information on the dominant microbial communities. The use of next generation sequencing techniques can provide a better insight on the real microbial diversity (Delmont et al. 2014).

The correlation between the ratio fixed $\mathrm{C}$ to volatile matter and microbial community composition in our study is probably due to the fact that this ratio is a powerful indicator of biochar carbonization degree. More fixed $\mathrm{C}$ and less volatile matter lead to greater impact on community composition. Contrary to our findings, we expected mild pyrolysis products with high volatile matter content to induce larger microbial community shifts in soil than high pyrolysis products. Available $\mathrm{C}$ is metabolized by microbes, and labile pools of $\mathrm{C}$ are known to decrease by increasing production temperature (Al-Wabel et al. 2013). The addition of non-carbonized feedstocks and hydrochars caused a small shift in soil microbial community composition while high-temperature biochars with lower volatile matter had a much greater effect. Therefore, available $\mathrm{C}$ did not have a strong effect on the microbial community composition, at least not after 1 year 
of incubation. As Chen et al. (2015) pointed out, a selection for species capable of decomposing "C-rich refractory material" is a more likely produced the shift in microbial community composition observed with biochars produced at increasing temperature. However, the molecular fingerprints we used here could not confirm this hypothesis. As already reported, only changes in the dominant microbial populations could be detected by TRFLP and ARISA.

Other studies using low taxonomic resolution techniques determined changes in dominant microbial communities of soil amended with biochar. Using phospholipid fatty acid fingerprints, Jiang et al. (2015) showed that biochar addition altered microbial community composition after 30 months of incubation mostly in favor of Gram (+) bacteria, confirming previous results obtained after shorter incubation (Bamminger et al. 2014b). In our study, changes observed on the dominant microbial populations may be explained by the modification of the soil microbial habitats Gul et al. 2015). As suggested by the RDA, these changes could be related to a combination of factors such as $\mathrm{pH}$ and organic composition of biochar as shown by the $\mathrm{O} / \mathrm{C}$ ratio, but also the content of inorganic elements like $\mathrm{Mg}$, and $\mathrm{K}$. All these factors may create new niches for rare microbial populations, and also affect the dominant populations.

The fact that the largest impact on soil microbial community composition was induced by high-temperature biochars is fully supported by the results of our second experiments where biochar was added to soil previously incubated with biochar. We observed that recently applied biochar mineralized fastest in soils previously incubated with hightemperature biochar (Fig. 2). The soil metabolic quotient is known to be affected by biochar amendments (Bamminger et al. 2014b; Ng et al. 2014) and several studies have shown a modified microbial activity after the addition of biochar (Mitchell et al. 2015). Our results from both microbial community composition and soil re-incubation indicate that the greatest impact on microbial communities is seen with hightemperature biochars.

\section{Conclusion}

Our results from a 1-year incubation study show that biochars with long residence time in soils can be produced from miscanthus and corncob feedstocks when a threshold temperature requirement of $370{ }^{\circ} \mathrm{C}$ is reached, and there is no gain in recalcitrance beyond this value. Molecular fingerprints indicate that changes in biochar properties affect both bacterial and fungal community composition and these effects increase by increasing production temperature up to $800{ }^{\circ} \mathrm{C}$. In particular, changes in $\mathrm{pH}$ and $\mathrm{O} / \mathrm{C}$ correlate with these microbial responses. The response of the soil microbial community is complex, with transient priming effects, increased change in community composition with biochar carbonization intensity, and increased biochar mineralization rate upon addition to soil previously exposed to biochar. The mechanisms behind these effects need to be better understood if we want to predict the long-term stability of biochar in soil.

Acknowledgments Authors are listed according to the sequencedetermines-credit approach. Funding for the research was provided by the Norwegian Research Council through the project "Advanced Techniques to Evaluate the Long-term Stability and Carbon Sequestration Potential of Different Types of Biochar", NFR197531. Slow pyrolysis biochars were provided by Morten Grønli and Liang Wang at the Norwegian University of Science and Technology. Flash carbonization char was provided by Michael Antal at Hawaii Natural energy Institute. Hydrochars were provided by Markus Antonietti at Max-Planck Institute for Colloids and Interfaces in Potsdam, Germany. Hege Bergheim is thanked for her assistance with laboratory measurements.

Open Access This article is distributed under the terms of the Creative Commons Attribution 4.0 International License (http:// creativecommons.org/licenses/by/4.0/), which permits unrestricted use, distribution, and reproduction in any medium, provided you give appropriate credit to the original author(s) and the source, provide a link to the Creative Commons license, and indicate if changes were made.

\section{References}

Al-Wabel MI, Al-Omran A, El-Naggar AH, Nadeem M, Usman ARA (2013) Pyrolysis temperature induced changes in characteristics and chemical composition of biochar produced from conocarpus wastes. Biores Technol 131:374-379. doi:10.1016/j.biortech.2012.12.165

Bai M, Wilske B, Buegger F, Esperschutz J, Kammann CI, Eckhardt C, Koestler M, Kraft P, Bach M, Frede HG, Breuer L (2013) Degradation kinetics of biochar from pyrolysis and hydrothermal carbonization in temperate soils. Plant Soil 372:375-387. doi:10. 1007/s11104-013-1745-6

Balesdent J, Mariotti A (1996) Measurement of soil organic matter turnover using 13C natural abundance. In: Boutton TW, Yamasaki SI (eds) Mass spectrometry of soils. Marcel Dekker, New York, pp 83-111

Bamminger C, Marschner B, Jüschke E (2014a) An incubation study on the stability and biological effects of pyrogenic and hydrothermal biochar in two soils. Eur J Soil Sci 65:72-82. doi:10.1111/ejss. 12074

Bamminger C, Zaiser N, Zinsser P, Lamers M, Kammann C, Marhan S (2014b) Effects of biochar, earthworms, and litter addition on soil microbial activity and abundance in a temperate agricultural soil. Biol Fert Soils 50:1189-1200. doi:10.1007/s00374-014-0968-x

Becker R, Dorgerloh U, Helmis M, Mumme J, Diakité M, Nehls I (2013) Hydrothermally carbonized plant materials: patterns of volatile organic compounds detected by gas chromatography. Biores Technol 130:621-628. doi:10.1016/j.biortech.2012.12.102

Blagodatskaya E, Kuzyakov Y (2008) Mechanisms of real and apparent priming effects and their dependence on soil microbial biomass and community structure: critical review. Biol Fert Soils 45:115-131. doi:10.1007/s00374-008-0334-y

Blaud A, Diouf F, Herrmann AM, Lerch TZ (2015) Analysing the effect of soil organic matter on bacterial communities using T-RFLP fingerprinting: different methods, different stories? Biol Fert Soils 51: 959-971. doi:10.1007/s00374-015-1041-0 
Braadbaart F, Boon JJ, van der Horst J, van Bergen PF (2004) Laboratory simulations of the transformation of peas as a result of heating: the change of the molecular composition by DTMS. J Anal App Pyrol 71:997-1026. doi:10.1016/j.jaap.2004.01.001

Budai A, Wang L, Gronli M, Strand LT, Antal MJ, Abiven S, DieguezAlonso A, Anca-Couce A, Rasse DP (2014) Surface properties and chemical composition of corncob and Miscanthus biochars: effects of production temperature and method. J Agric Food Chem 62: 3791-3799. doi:10.1021/jf501139f

Calucci L, Rasse DP, Forte C (2013) Solid-state nuclear magnetic resonance characterization of chars obtained from hydrothermal carbonization of corncob and miscanthus. Energy Fuel 27:303-309. doi: 10.1021/ef3017128

Chen J, Liu X, Li L, Zheng J, Qu J, Zheng J, Zhang X, Pan G (2015) Consistent increase in abundance and diversity but variable change in community composition of bacteria in topsoil of rice paddy under short term biochar treatment across three sites from South China. Appl Soil Ecol 91:68-79. doi:10.1016/j.apsoil.2015.02.012

Cheng CH, Lehmann J, Thies JE, Burton SD (2008) Stability of black carbon in soils across a climatic gradient. J Geophys Res-Biogeosci 113:10. doi:10.1029/2007jg000642

Conti R, Rombolà AG, Modelli A, Torri C, Fabbri D (2014) Evaluation of the thermal and environmental stability of switchgrass biochars by Py-GC-MS. J Anal App Pyrol 110:239-247. doi:10.1016/j.jaap. 2014.09.010

Creamer AE, Gao B, Zhang M (2014) Carbon dioxide capture using biochar produced from sugarcane bagasse and hickory wood. Chem Eng J 249:174-179. doi:10.1016/j.cej.2014.03.105

Delmont TO, Francioli D, Jacquesson S, Laoudi S, Mathieu A, Nesme J, Ceccherini MT, Nannipieri P, Simonet P, Vogel TM (2014) Microbial community development and unseen diversity recovery in inoculated sterile soil. Biol Fert Soils 50:1069-1076. doi:10. 1007/s00374-014-0925-8

Enders A, Hanley K, Whitman T, Joseph S, Lehmann J (2012) Characterization of biochars to evaluate recalcitrance and agronomic performance. Biores Technol 114:644-653. doi:10.1016/j.biortech. 2012.03.022

Fang Y, Singh B, Singh BP (2015) Effect of temperature on biochar priming effects and its stability in soils. Soil Biol Biochem 80: 136-145. doi:10.1016/j.soilbio.2014.10.006

Farrell M, Kuhn TK, Macdonald LM, Maddern TM, Murphy DV, Hall PA, Singh BP, Baumann K, Krull ES, Baldock JA (2013) Microbial utilisation of biochar-derived carbon. Sci Total Environ 465:288297. doi:10.1016/j.scitotenv.2013.03.090

Fierer N, Jackson RB (2006) The diversity and biogeography of soil bacterial communities. Proc Natl Ac Sci Unit Stat Am 103:626631. doi:10.1073/pnas.0507535103

Fontaine S, Bardoux G, Abbadie L, Mariotti A (2004) Carbon input to soil may decrease soil carbon content. Ecol Lett 7:314-320. doi:10. 1111/j.1461-0248.2004.00579.x

Gardes M, Bruns TD (1993) ITS primers with enhanced specificity for basidiomycetes - application to the identification of mycorrhizae and rusts. Molec Ecol 2:113-118. doi:10.1111/j.1365-294X.1993. tb00005.x

Graber ER, Harel YM, Kolton M, Cytryn E, Silber A, David DR, Tsechansky L, Borenshtein M, Elad Y (2010) Biochar impact on development and productivity of pepper and tomato grown in fertigated soilless media. Plant Soil 337:481-496. doi:10.1007/ s11104-010-0544-6

Graber ER, Tsechansky L, Gerstl Z, Lew B (2012) High surface area biochar negatively impacts herbicide efficacy. Plant Soil 353:95106. doi:10.1007/s11104-011-1012-7

Gul S, Whalen JK, Thomas BW, Sachdeva V, Deng H (2015) Physicochemical properties and microbial responses in biochar-amended soils: mechanisms and future directions. Agr Ecosyst Environ 206: 46-59. doi:10.1016/j.agee.2015.03.015
Hernandez-Soriano MC, Kerré B, Goos P, Hardy B, Dufey J, Smolders E (2015) Long-term effect of biochar on the stabilization of recent carbon: soils with historical inputs of charcoal. Glob Change Biol Bioenerg.12250. doi:10.1111/gcbb.12250

Jandl G, Eckhardt KU, Bargmann I, Kucke M, Greef JM, Knicker H, Leinweber P (2013) Hydrothermal carbonization of biomass residues: mass spectrometric characterization for ecological effects in the soil-plant system. J Environ Qual 42:199-207. doi:10.2134/ jeq2012.0155

Jiang X, Denef K, Stewart CE, Cotrufo MF (2015) Controls and dynamics of biochar decomposition and soil microbial abundance, composition, and carbon use efficiency during long-term biochar-amended soil incubations. Biol Fert Soils 52:1-14. doi:10.1007/s00374-0151047-7

Kammann C, Ratering S, Eckhard C, Muller C (2012) Biochar and hydrochar effects on greenhouse gas (carbon dioxide, nitrous oxide, and methane) fluxes from soils. J Environ Qual 41:1052-1066. doi: 10.2134/jeq2011.0132

Kolton M, Harel YM, Pasternak Z, Graber ER, Elad Y, Cytryn E (2011) Impact of biochar application to soil on the rootassociated bacterial community structure of fully developed greenhouse pepper plants. Appl Environ Microb 77:49244930. doi:10.1128/aem.00148-11

Kuzyakov Y, Bogomolova I, Glaser B (2014) Biochar stability in soil: decomposition during eight years and transformation as assessed by compound-specific C-14 analysis. Soil Biol Biochem 70:229-236. doi:10.1016/j.soilbio.2013.12.021

Kuzyakov Y, Subbotina I, Chen HQ, Bogomolova I, Xu XL (2009) Black carbon decomposition and incorporation into soil microbial biomass estimated by C-14 labeling. Soil Biol Biochem 41:210-219. doi:10. 1016/j.soilbio.2008.10.016

Legendre P, Fortin MJ (1989) Spatial pattern and ecological analysis. Vegetatio 80:107-138. doi:10.1007/bf00048036

Lehmann J, Rillig MC, Thies J, Masiello CA, Hockaday WC, Crowley D (2011) Biochar effects on soil biota - a review. Soil Biol Biochem 43:1812-1836. doi:10.1016/j.soilbio.2011.04.022

Li M, Liu Q, Lou Z, Wang Y, Zhang Y, Qian G (2014) Method to characterize acid-base behavior of biochar: site modeling and theoretical simulation. ACS Sustain Chem Eng 2:2501-2509. doi:10.1021/ sc500432d

Luo Y, Durenkamp M, De Nobili M, Lin Q, Brookes PC (2011) Short term soil priming effects and the mineralisation of biochar following its incorporation to soils of different $\mathrm{pH}$. Soil Biol Biochem 43: 2304-2314. doi:10.1016/j.soilbio.2011.07.020

Maestrini B, Nannipieri P, Abiven S (2014) A meta-analysis on pyrogenic organic matter induced priming effect. Glob Change Biol Bioenerg 7:577-590. doi:10.1111/gcbb.12194

Malghani S, Gleixner G, Trumbore SE (2013) Chars produced by slow pyrolysis and hydrothermal carbonization vary in carbon sequestration potential and greenhouse gases emissions. Soil Biol Biochem 62:137-146. doi:10.1016/j.soilbio.2013.03.013

Marchesi JR, Sato T, Weightman AJ, Martin TA, Fry JC, Hiom SJ, Wade WG (1998) Design and evaluation of useful bacterium-specific pcr primers that amplify genes coding for bacterial 16s rRNA. Appl Environ Microb 64:795-799

Marschner B, Brodowski S, Dreves A, Gleixner G, Gude A, Grootes PM, Hamer U, Heim A, Jandl G, Ji R, Kaiser K, Kalbitz K, Kramer C, Leinweber P, Rethemeyer J, Schaeffer A, Schmidt MWI, Schwark L, Wiesenberg GLB (2008) How relevant is recalcitrance for the stabilization of organic matter in soils? J Plant Nutr Soil Sc 171: 91-110. doi:10.1002/jpln.200700049

Masek O, Brownsort P, Cross A, Sohi S (2013) Influence of production conditions on the yield and environmental stability of biochar. Fuel 103:151-155. doi:10.1016/j.fuel.2011.08.044

Mitchell PJ, Simpson AJ, Soong R, Simpson MJ (2015) Shifts in microbial community and water-extractable organic matter composition 
with biochar amendment in a temperate forest soil. Soil Biol Biochem 81:244-254. doi:10.1016/j.soilbio.2014.11.017

Moni C, Lerch TZ, Knoth de Zarruk K, Strand LT, Forte C, Certini G, Rasse DP (2015) Temperature response of soil organic matter mineralisation in arctic soil profiles. Soil Biol Biochem 88:236246. doi:10.1016/j.soilbio.2015.05.024

Moni C, Rasse DP (2014) Detection of simulated leaks from geologically stored $\mathrm{CO} 2$ with C-13 monitoring. Int J Greenh Gas Control 26:6168. doi:10.1016/j.ijggc.2014.04.010

Ng EL, Patti AF, Rose MT, Schefe CR, Wilkinson K, Smernik RJ, Cavagnaro TR (2014) Does the chemical nature of soil carbon drive the structure and functioning of soil microbial communities? Soil Biol Biochem 70:54-61. doi:10.1016/j.soilbio.2013.12.004

Nguyen BT, Koide RT, Dell C, Drohan P, Skinner H, Adler PR, Nord A (2014) Turnover of soil carbon following addition of switchgrassderived biochar to four soils. Soil Sci Soc Am J 78:531-537. doi:10. 2136/sssaj2013.07.0258

Noble IR, Apps MJ, Houghton RA, Lashof DA, Makundi W, Murdiyarso D, Murray B, Sombroek W, Valentini R, Amano M, Fearnside P, Frangi J, Frumhoff P, Goldberg D, Higuchi N, Janetos A, Kirschbaum M, Lasco R, Nabuurs G, Persson R, Schlesinger W, Shvidenko A, Skole D, Smith P (2000) Implications of different definitions and generic issues. In: Watson RT, Noble IR, Bolin B, Ravindranath NH, Verardo DJ, Dokken DJ (Eds) Land use, land use change and forestry. Cambridge, UK, pp 55-126

Prayogo C, Jones JE, Baeyens J, Bending GD (2014) Impact of biochar on mineralisation of $\mathrm{C}$ and $\mathrm{N}$ from soil and willow litter and its relationship with microbial community biomass and structure. Biol Fert Soils 50:695-702. doi:10.1007/s00374-013-0884-5

Preston CM, Schmidt MWI (2006) Black (pyrogenic) carbon: a synthesis of current knowledge and uncertainties with special consideration of boreal regions. Biogeosciences 3:397-420. doi:10.5194/bg-3-3972006

Qiao N, Schaefer D, Blagodatskaya E, Zou XM, Xu XL, Kuzyakov Y (2014) Labile carbon retention compensates for $\mathrm{CO} 2$ released by priming in forest soils. Glob Change Biol 20:1943-1954. doi:10. $1111 / \mathrm{gcb} .12458$

Quilliam RS, Glanville HC, Wade SC, Jones DL (2013) Life in the 'charosphere' - does biochar in agricultural soil provide a significant habitat for microorganisms? Soil Biol Biochem 65:287-293. doi:10.1016/j.soilbio.2013.06.004

Rousk J, Brookes PC, Bååth E (2010) The microbial PLFA composition as affected by $\mathrm{pH}$ in an arable soil. Soil Biol Biochem 42:516-520. doi:10.1016/j.soilbio.2009.11.026

Schmidt MWI, Torn MS, Abiven S, Dittmar T, Guggenberger G, Janssens IA, Kleber M, Kogel-Knabner I, Lehmann J, Manning DAC, Nannipieri P, Rasse DP, Weiner S, Trumbore SE (2011) Persistence of soil organic matter as an ecosystem property. Nature 478:49-56. doi:10.1038/nature10386
Schulze M, Mumme J, Funke A, Kern J (2016) Effects of selected process conditions on the stability of hydrochar in low-carbon sandy soil. Geoderma 267:137-145. doi:10.1016/j.geoderma.2015.12.018

Singh BP, Cowie AL (2014) Long-term influence of biochar on native organic carbon mineralisation in a low-carbon clayey soil. Sci Rep 4:9. doi: $10.1038 / \mathrm{srep} 03687$

Singh BP, Cowie AL, Smernik RJ (2012) Biochar carbon stability in a clayey soil as a function of feedstock and pyrolysis temperature. Environ Sci Technol 46:11770-11778. doi:10.1021/es302545b

Singh T, Singh AP, Hussain I, Hall P (2013) Chemical characterisation and durability assessment of torrefied radiata pine (Pinus radiata) wood chips. International Biodeterioration \& Biodegradation 85: 347-353. doi:10.1016/j.ibiod.2013.07.014

Ventura M, Alberti G, Viger M, Jenkins JR, Girardin C, Baronti S, Zaldei A, Taylor G, Rumpel C, Miglietta F, Tonon G (2014) Biochar mineralization and priming effect on SOM decomposition in two European short rotation coppices. Glob Change Biol Bioenerg 7: 1150-1160. doi:10.1111/gcbb.12219

Wang J, Xiong Z, Kuzyakov Y (2015) Biochar stability in soil: metaanalysis of decomposition and priming effects. Glob Change Biol Bioenerg. doi:10.1111/gcbb.12266

Watzinger A, Feichtmair S, Kitzler B, Zehetner F, Kloss S, Wimmer B, Zechmeister-Boltenstern S, Soja G (2014) Soil microbial communities responded to biochar application in temperate soils and slowly metabolized 13C-labelled biochar as revealed by 13C PLFA analyses: results from a short-term incubation and pot experiment. Eur J Soil Sci 65:40-51. doi:10.1111/ejss. 12100

White T, Bruns T, Lee S, Taylor J (1990) Amplification and direct sequencing of fungal ribosomal RNA genes for phylogenetics. In: Innis M, Gelfand D, Shinsky J, White T (Eds) PCR Protocols: A Guide to Methods and Applications. Academic Press, London, pp 315-322. doi:citeulike-article-id:671166

Whitman T, Hanley K, Enders A, Lehmann J (2013) Predicting pyrogenic organic matter mineralization from its initial properties and implications for carbon management. Org Geochem 64:76-83. doi:10. 1016/j.orggeochem.2013.09.006

Woolf D, Amonette JE, Street-Perrott FA, Lehmann J, Joseph S (2010) Sustainable biochar to mitigate global climate change. Nature Commun 1. doi:10.1038/ncomms1053

Yuan JH, Xu RK, Zhang H (2011) The forms of alkalis in the biochar produced from crop residues at different temperatures. Biores Technol 102:3488-3497. doi:10.1016/j.biortech.2010.11.018

Zhang J, Liu J, Liu R (2015) Effects of pyrolysis temperature and heating time on biochar obtained from the pyrolysis of straw and lignosulfonate. Biores Technol 176:288-291. doi:10.1016/j.biortech.2014. 11.011

Zimmerman AR, Gao B, Ahn MY (2011) Positive and negative carbon mineralization priming effects among a variety of biochar-amended soils. Soil Biol Biochem 43:1169-1179. doi:10.1016/j.soilbio.2011. 02.005 